\title{
Erratum: DeconPeaker, a Deconvolution Model to Identify Cell Types Based on Chromatin Accessibility in ATAC-Seq Data of Mixture Samples
}

\author{
Frontiers Production Office* \\ Frontiers Media SA, Lausanne, Switzerland
}

Keywords: chromatin accessibility, cell type, deconvolution, mixture samples, gene expression

\section{OPEN ACCESS}

Approved by:

Frontiers Editorial Office,

Frontiers Media SA, Switzerland

*Correspondence:

Frontiers Production Office production.office@frontiersin.org

Specialty section:

This article was submitted to Computational Genomics,

a section of the journal

Frontiers in Genetics

Received: 04 June 2020

Accepted: 05 June 2020

Published: 15 June 2020

Citation:

Frontiers Production Office (2020)

Erratum: DeconPeaker, a Deconvolution Model to Identify Cell

Types Based on Chromatin

Accessibility in ATAC-Seq Data of

Mixture Samples.

Front. Genet. 11:693.

doi: 10.3389/fgene.2020.00693

\section{An Erratum on}

DeconPeaker, a Deconvolution Model to Identify Cell Types Based on Chromatin Accessibility in ATAC-Seq Data of Mixture Samples

by Li, H., Sharma, A., Luo, K., Qin, Z. S., Sun, X., and Liu, H. (2020). Front. Genet. 11:392. doi: $10.3389 /$ fgene.2020.00392

Due to a typesetting error, many of the references were cited in the wrong place. In addition the citations in the legends for Figures $2 \mathrm{~F}$ and $7 \mathrm{C}$ were incorrect. In the former, "Jia et al." should be "Jia et al. (2018)". In the latter, "Corces et al." should be "Corces et al. (2016)". The publisher apologizes for this mistake. The original version of this article has been updated.

\section{REFERENCES}

Corces, M. R., Buenrostro, J. D., Wu, B., Greenside, P. G., Chan, S. M., Koenig, J. L., et al. (2016). Lineage-specific, and single-cell chromatin accessibility charts human hematopoiesis and leukemia evolution. Nat. Genet. 48, 1193-1203. doi: $10.1038 / \mathrm{ng} .3646$

Jia, G., Preussner, J., Chen, X., Guenther, S., Yuan, X., Yekelchyk, M., et al. (2018). Single cell RNA-seq and ATAC-seq analysis of cardiac progenitor cell transition states and lineage settlement. Nat. Commun. 9:4877. doi: 10.1038/s41467-018-07307-6

Copyright $(2020$ Frontiers Production Office. This is an open-access article distributed under the terms of the Creative Commons Attribution License (CC BY). The use, distribution or reproduction in other forums is permitted, provided the original author(s) and the copyright owner(s) are credited and that the original publication in this journal is cited, in accordance with accepted academic practice. No use, distribution or reproduction is permitted which does not comply with these terms. 